\title{
Pelaksanaan discharge planning pada pasien diabetes melitus: Studi literatur
}

\author{
Linda Yulia, Hj. Tuti Pahria, Sandra Pebrianti ${ }^{*}$ \\ Departemen Keperawatan Medikal Bedah, Fakultas Keperawatan, Universitas Padjadjaran, Indonesia \\ *Email: sandra.pebrianti@unpad.ac.id
}

\begin{abstract}
Discharge planning from hospital to home among patients with diabetes mellitus: A literature study
\end{abstract}

Background: Several studies have stated that patients with diabetes mellitus who do not get proper management when discharge after hospitalization are very at risk to readmission because of complications. Properly discharge planning programme is very essentials to reduce the number of readmission and following by controlled on patient's conditions. However, the fruitfulness level of discharge planning program in each hospital was different. planning in DM patients is still not optimal and does not explain in detail the discharge planning stages.

Purpose: To determine several studies of discharge planning programme among patients with diabetes mellitus in several hospital

Method: Literature study method with narrative review approach. Search for articles using databases by Science Direct, Pubmed and Google Scholar by entering keywords "discharge planning or return planning, Stages or steps, Diabetes or glycemic." From the search results, there were 13,743 articles that matched the keywords, then an examination carried out based on inclusion criteria (published year 2011-2020, articles in Indonesian and English, using the retrospect cohort method, RCT, and Quasi Experiment, full-text articles, discuss discharge planning stages) and exclusion criteria (articles on systematic reviews, proceedings, editorials and books). An examination carried out based on the title, sample, research method, and getting 10 articles.

Results: Analyzing result of 10 articles found that the discharge planning stage was the first stage starting from the time when admitting to hospital by conducting an assessment, diagnosis, planning, implementation and evaluation. The second stage was for the patient treated by providing education and training. Providing education included information about disease, signs and symptoms of disease, things that must avoid from experienced health problems and complications, and information about health service sources in the community. While training included the use of drugs, insulin, diet, physical activity, management of hypo and hyperglycemia, foot care, and blood glucose control. The third stage was after the patient discharged from the hospital by following up in form of telephone counseling and visits to the patient's home. The result of this literature study can be used as learning material for further research and material in providing nursing care.

\section{Keywords: Discharge planning; Hospital; Patients; Diabetes mellitus; Literature study}

Pendahuluan: Pasien DM yang tidak mendapatkan penatalaksanaan yang tepat sangat beresiko mengalami berbagai komplikasi. Beberapa penelitian menyebutkan pasien DM cenderung kembali menjalani rawat ulang setelah pulang dari rumah sakit akibat dari komplikasi. Discharge planning terbukti dapat mengurangi jumlah kunjungan ulang ke rumah sakit dengan keluhan yang sama dan bahkan dapat mengurangi tingkat komplikasi. Namun, untuk saat ini, pelaksanaan discharge planning pada pasien DM masih kurang optimal dan tidak secara rinci menjelaskan tentang tahapan discharge planning.

Tujuan: Untuk mengetahui tahapan dalam pemberian discharge planning pada pasien diabetes melitus.

Metode: Penelitian ini menggunakan metode studi literatur dengan pendekatan narrative review. Pencarian artikel menggunakan database yaitu Science Direct, Pubmed dan Google Scholar dengan memasukkan kata kunci yaitu "discharge planning or perencanaan pulang, Stages or tahapan, Diabetes or glycemic. Dari hasil pencarian ditemukan sebanyak 13,743 artikel yang sesuai dengan kata kunci, kemudian dilakukan pemeriksaan berdasarkan kriteria inklusi (terbit tahun 2011-2020, artikel dalam Bahasa Indonesia dan Bahasa Inggris, menggunakan metode kohort retrospekti, RCT, dan Quasi Experiment, artikel tersedia full text, membahas tahapan discharge planning) serta kriteria eksklusi (Artikel systematic review, proceeding, editorial dan buku). 
Selanjutnya dilakukan pemeriksaan berdasarkan judul, sampel, metode penelitian, dan isi sehingga didapatkan 10 artikel.

Hasil: Dari 10 artikel ditemukan tahapan discharge planning tahap pertama dimulai sejak pasien masuk ke rumah sakit dengan melakukan pengkajian, diagnosa, perencanaan, implementasi, dan evaluasi. Tahap kedua selama pasien di rawat dengan memberikan pendidikan dan pelatihan. Pemberian pendidikan meliputi informasi tentang penyakit, tanda dan gejala penyakit, hal-hal yang harus dihindarkan dari gangguan kesehatan yang dialami dan komplikasi, serta informasi tentang sumber-sumber pelayanan kesehatan dimasyarakat. Sedangkan pelatihan meliputi penggunaan obat dan insulin, diet, aktivitas fisik, manajemen hipo dan hiperglikemia, perawatan kaki, dan kontrol glukosa darah. Tahap ketiga yaitu setelah pasien keluar dari rumah sakit dengan melakukan tindak lanjut berupa konseling telepon dan kunjungan ke rumah pasien. Hasil studi literatur ini dapat dijadikan sebagai bahan pembelajaran untuk penelitian selanjutnya dan bahan dalam memberikan asuhan keperawatan oleh perawat pada pasien diabetes melitus.

\section{Kata Kunci: Pelaksanaan; Discharge planning; Pasien; Diabetes melitus; Studi literatur}

\section{PENDAHULUAN}

Prevalensi DM mengalami peningkatan empat kali lipat dibandingkan tahun 1980 sebesar 415 juta orang. Pada tahun 2012 DM menjadi salah satu penyakit yang mengakibatkan kematian 3,7 juta orang di dunia. Angka kematian yang disebabkan oleh DM sering dialami sebelum usia 70 tahun (WHO Global Report, 2016). Angka prevalensi DM akan terus meningkat menjadi 642 di tahun 2040 mendatang (International Diabetes Federation , 2015).

DM adalah suatu penyakit yang ditandai peningkatan kadar glukosa darah yang melebihi batas (Nabila, 2018). Kenaikan kadar glukosa darah pada pasien DM disebabkan akibat kelainan pankreas yang tidak dapat menghasilkan insulin atau saat tubuh tidak dapat menggunakan insulin secara efektif (Puspita \& Rakhman, 2018). Di kondisi yang normal, insulin akan berikatan dengan reseptor khusus di permukaan sel dan menjadikan suatu reaksi metabolisme didalam sel (Pujiastuti, 2016). Namun saat resistensi insulin, reseptor khusus tidak dapat berespon pada insulin sehingga insulin dan reseptor tidak dapat berikatan.

Jika tidak mendapatkan penatalaksanaan yang tepat penyakit DM dapat mengakibatkan berbagai komplikasi yang akan mengenai seluruh bagian tubuh. Komplikasi jangka panjang yang dapat ditimbulkan diantaranya stroke, gagal jantung, nefropati, retinopati dan neuropati (Wu et al, 2014). Neuropati perifer adalah komplikasi yang paling sering dialami pasien DM yaitu berkisar 10\% sampai $60 \%$ timbulnya ulkus diabetik yang merupakan penyebab utama tindakan amputasi (Staff, 2012; Taharuddin, 2017). Pada kenyataannya pasien DM sering mengalami rehospitalisasi akibat komplikasi (Zahroh \&
Azkiyawati, 2015). Komplikasi pada pasien DM mengakibatkan $47 \%$ pasien kembali menjalani rawat ulang setelah pulang dari rumah sakit (Alloghani et al, 2019). Penelitian lain juga mengungkapkan bahwa 33,3\% pasien DM kembali mengalami rawat ulang akibat tidak patuh mengikuti anjuran pemeriksaan glukosa darah (Amtsalina, 2016).

Meskipun pasien dan keluarga sudah mendapatkan penjelasan dari tenaga kesehatan mereka cenderung tidak mengikuti anjuran yang diberikan disebabkan informasi yang disampaikan dinilai kurang adekuat sehingga pasien dan keluarga tidak tahu bagaimana cara mengimplementasikannya serta pasien dan keluarga tidak berada pada situasi yang ideal dalam persiapan menghadapi pemulangan (Soegondo, 2013). Ketidaksiapan pasien dalam menghadapi pemulangan dapat mengakibatkan pasien mengalami keadaan yang lebih buruk atau meningkatkan komplikasi penyakit yang berulang (Huda, Ramayanti, \& Nur , 2014). Salah satu bentuk pelayanan kesehatan yang dapat dilakukan dalam mempersiapkan pasien menghadapi pemulangan adalah melalui discharge planning. Discharge planning merupakan program pemberian pendidikan kesehatan pada pasien dan keluarga pada saat sebelum dan sesudah pasien keluar dari rumah sakit yang bertujuan agar pasien dapat mencapai kesehatan yang optimal (Natasia, 2014).

Discharge planning bermanfaat dalam mengurangi jumlah kunjungan ulang ke rumah sakit dengan keluhan yang sama dan bahkan dapat mengurangi tingkat komplikasi (Graham et al, 2013). Discharge planning juga dapat mengurangi LOS (durasi menginap) dan biaya 
Pelaksanaan discharge planning pada pasien diabetes melitus: Studi literatur

perawatan (Wrobleski et al, 2014). Setelah diberikan discharge planning $87,5 \%$ pasien DM mempunyai tingkat kesiapan yang baik dalam menghadapi proses pemulangan (Fitri,2020). Pemberian discharge planning memiliki pengaruh yang signifikan terhadap kemampuan perawatan diri pada pasien DM yang lebih baik (Astuti, Suhartono, \& Sulisno 2016).

Pelaksanaan discharge planning pada umumnya dilakukan hanya untuk melengkapi administrasi pada catatan pulang pasien dan pemberian informasi singkat tentang informasi penggunaan obat, diet dan waktu kontrol (Purwanti, Yusuf, \& Suprajitno 2016). Hal tersebut tidak dapat dikatakan discharge planning sebab hanya diberikan dalam waktu singkat dan informasi yang sangat terbatas sehingga tidak menjamin suatu perubahan perilaku pasien dan keluarga (Darliana, 2012).

Pelaksanaan discharge planning yang tidak efektif dapat menyebabkan terputusnya kontinuitas perawatan ketika pasien di rumah dan meningkatkan ketergantungan pasien dalam pengobatan (Firmawati, 2017). Kondisi ini dapat menyebabkan terjadinya perburukan kondisi pasien sehingga pasien beresiko kembali ke rumah sakit dengan penyakit yang sama ataupun komplikasi penyakit yang lebih berat. Akibat proses discharge planning yang belum dilakukan secara maksimal 11 pasien mengalami rawat ulang dimana 6 orang $(54,5 \%)$ diantaranya dirawat kembali terkait proses penyakit yang sama sebelumnya dan 5 orang dirawat kembali bukan dari proses penyakit sebelumnya (Hardivianty, 2017).

Petugas kesehatan harus memberikan discharge planning sedini mungkin dan mempersiapkan tahapan discharge planning yang perlu diberikan sejak pasien masuk ke rumah sakit sehingga pasien dapat melakukan pengelolaan penyakit secara mandiri setelah keluar dari rumah sakit (Jannah, Sukartini, \& Hidayat, 2019).

Pelaksanaan discharge planning yang dilakukan secara terstruktur akan mendukung kontinuitas pelayanan kesehatan, terbukti $92 \%$ perawat yang melakukan discharge planning dengan baik dapat memberikan pelayanan sesuai dengan kebutuhan pasien (Tage, Novieastari, \& Suhendri, 2018). Selain itu perawat yang berperan sebagai edukator dalam memberikan discharge planning dapat meningkatkan kepatuhan pasien rawat inap untuk melakukan kontrol ke rumah sakit (Suryadi, 2013). Oleh sebab itu, tenaga kesehatan terutama perawat diharapkan dapat melaksanakan discharge planning dengan optimal dimulai dari pengkajian ketika pasien masuk hingga pasien keluar rumah sakit (Agustin, 2017).

Berdasarkan uraian di atas, tergambarkan bahwa sebagian besar pasien DM cenderung mengalami rawat ulang setelah keluar dari rumah sakit akibat dari perburuan penyakitnya. Hal ini disebabkan ketidaksiapan pasien dalam menghadapi pemulangan dikarenakan informasi yang diterima oleh pasien dan keluarga yang sangat terbatas selama perawatan sehingga pasien dan keluarga tidak tahu bagaimana cara penatalaksanaan penyakit yang baik saat berada di rumah, salah satu cara untuk mempersiapkan pasien dalam menghadapi pemulangan adalah melalui discharge planning. Untuk itu perlu informasi yang jelas tentang bagaimana tahapan discharge planning pada pasien DM. Sehingga perlu adanya kajian studi literatur yang membahas tentang gambaran discharge planning pada pasien diabetes melitus.

\section{METODE PENELITIAN}

Studi literatur ini menggunakan metode pendekatan narrative review yaitu penelitian yang tidak memiliki pertanyaan atau strategi pencarian penelitian tertentu, dan bukan pendekatan yang sistematis dan mengikuti protokol aturan baku tertentu (Demiris, Oliver, \& Washington, 2019). Sumber data yang didapatkan dari literatur yang diperoleh dari internet yang berupa hasil publikasi penelitian jurnal bahasa Indonesia dan inggris. Kriteria inklusi dalam penelitian ini berfokus pada tahapan discharge planning pada pasien diabetes melitus dan menggunakan data sekunder yang diambil dari jurnal ilmiah nasional maupun internasional dari tahun 2011-2020.

Untuk penelitian dengan pendekatan narrative review ini menggunakan skala SANRA dalam penilaian artikel yang dicari sesuai dengan topik. Skala ini dimaksudkan untuk membantu penulis menilai kualitas artikel berdasarkan kriteria formal yang tersedia. Kriteria penilaian mencakup justifikasi artikel, perumusan tujuan konkret, deskripsi pencarian literatur, referensi, bukti ilmiah dan penyajian data yang sesuai (Baethge et al, 2019).

Setelah artikel yang sesuai didapatkan kemudian artikel dibuat ringkasan yang meliputi nama penulis, tahun terbit, judul artikel, sampel, desain penelitian, lokasi penelitian, intervensi dan hasil penelitian. Ringkasan artikel tersebut dimasukan ke dalam tabel dan diurutkan sesuai format diatas. Semua artikel dicermati dan dibaca sepenuhnya kemudian dilakukan analisis untuk mengkritisi setiap artikel. Analisis yang digunakan yaitu analisis isi artikel terhadap isi artikel yang terdapat kategori tahapan discharge planning pada pasien diabetes melitus. Data yang terkumpul kemudian dicari persamaan dan perbedaannya lalu dibahas untuk menarik kesimpulan. 
HASIL

(Gambar 1. Proses Pemilihan Literatur)

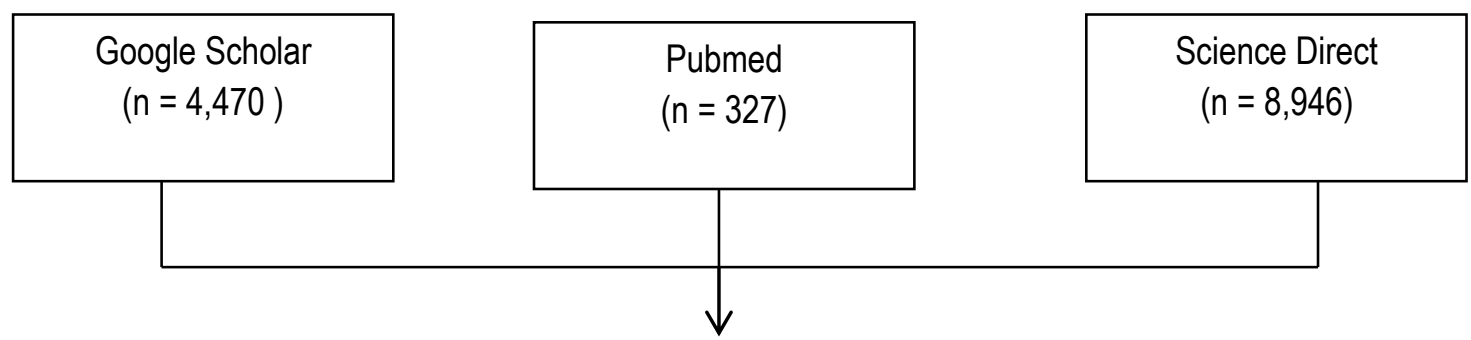

Artikel dieliminasi berdasarkan duplikasi ( $\mathrm{n}=7$ artikel) 
Tabel . Analisa literatur

\begin{tabular}{|c|c|c|c|c|c|c|c|}
\hline No & Judul & $\begin{array}{l}\text { Penulis dan } \\
\text { Tahun Terbit }\end{array}$ & $\begin{array}{c}\text { Tujuan } \\
\text { Penelitian }\end{array}$ & Asal Negara & $\begin{array}{l}\text { Metode dan } \\
\text { Sampel }\end{array}$ & Hasil penelitian & Database \\
\hline 1 & $\begin{array}{l}\text { Effect of } \\
\text { discharge } \\
\text { planning on } \\
\text { metabolic } \\
\text { factors in type } \\
2 \text { diabetic } \\
\text { patients }\end{array}$ & $\begin{array}{l}\text { Alemeh Dehnabi, } \\
\text { Hassan } \\
\text { Navipour, Hamid } \\
\text { Radsepehr, } \\
\text { Musa al- Reza } \\
\text { Tadayonfar } \\
\text { (2017) }\end{array}$ & $\begin{array}{l}\text { Tujuan penelitian } \\
\text { ini } \\
\text { mengetahui } \\
\text { pengaruh } \\
\text { discharge planning } \\
\text { terhadap faktor } \\
\text { metabolik pada } \\
\text { pasien DM }\end{array}$ & Iran & $\begin{array}{l}\text { Penelitian ini } \\
\text { adalah penelitian } \\
\text { semi } \\
\text { eksperimental } \\
\text { Sampel yang } \\
\text { digunakan } \\
\text { berjumlah } \quad 70 \\
\text { responden }\end{array}$ & $\begin{array}{l}\text { Penelitian ini menjelaskan tiga tahapan } \\
\text { discharge planning. Tahap pertama } \\
\text { dilakukan pada saat pasien masuk } \\
\text { rumah sakit dengan melakukan } \\
\text { pengkajian, menetapkan diagnosis, } \\
\text { perencanaan dan implementasi. Tahap } \\
\text { kedua dilakukan selama pasien di } \\
\text { rawat, setelah informasi dikumpulkan } \\
\text { dan penetapan diagnosa, } \\
\text { perencanaan dan pelatihan dimulai } \\
\text { perencanaan disesuaikan dengan } \\
\text { tingkat kebutuhan pendidikan dan } \\
\text { pelathan pasien, pendidikan perawatan } \\
\text { diri diberikan dalam enam sesi } \\
\text { pertemuan. Pada implementasi } \\
\text { discharge planning dimulai dari saat } \\
\text { pasien masuk dan berlanjut sampai dua } \\
\text { bulan setelah keluar dari rumah sakit. } \\
\text { Pada tahap ketiga dilakukan setelah } \\
\text { pasien keluar dari rumah sakit dengan } \\
\text { pemberian tindak lanjut dengan } \\
\text { panggilan telepon seminggu sekali dan } \\
\text { kunjungan langsung setiap dua minggu } \\
\text { ke rumah pasien. } \\
\text { Hasil penelitian ini menunjukan pasien } \\
\text { yang diberikan discharge planning } \\
\text { mengalami peningkatan beberapa } \\
\text { faktor metabolisme (hemoglobin } \\
\text { glikosilasi, trigliserida, tekanan darah } \\
\text { sistolik) }\end{array}$ & Pubmed \\
\hline
\end{tabular}

Linda Yulia, Hj. Tuti Pahria, Sandra Pebrianti ${ }^{*}$

Departemen Keperawatan Medikal Bedah, Fakultas Keperawatan, Universitas Padjadjaran, Indonesia *Email: sandra.pebrianti@unpad.ac.id 
Pelaksanaan discharge planning pada pasien diabetes melitus: Studi literatur

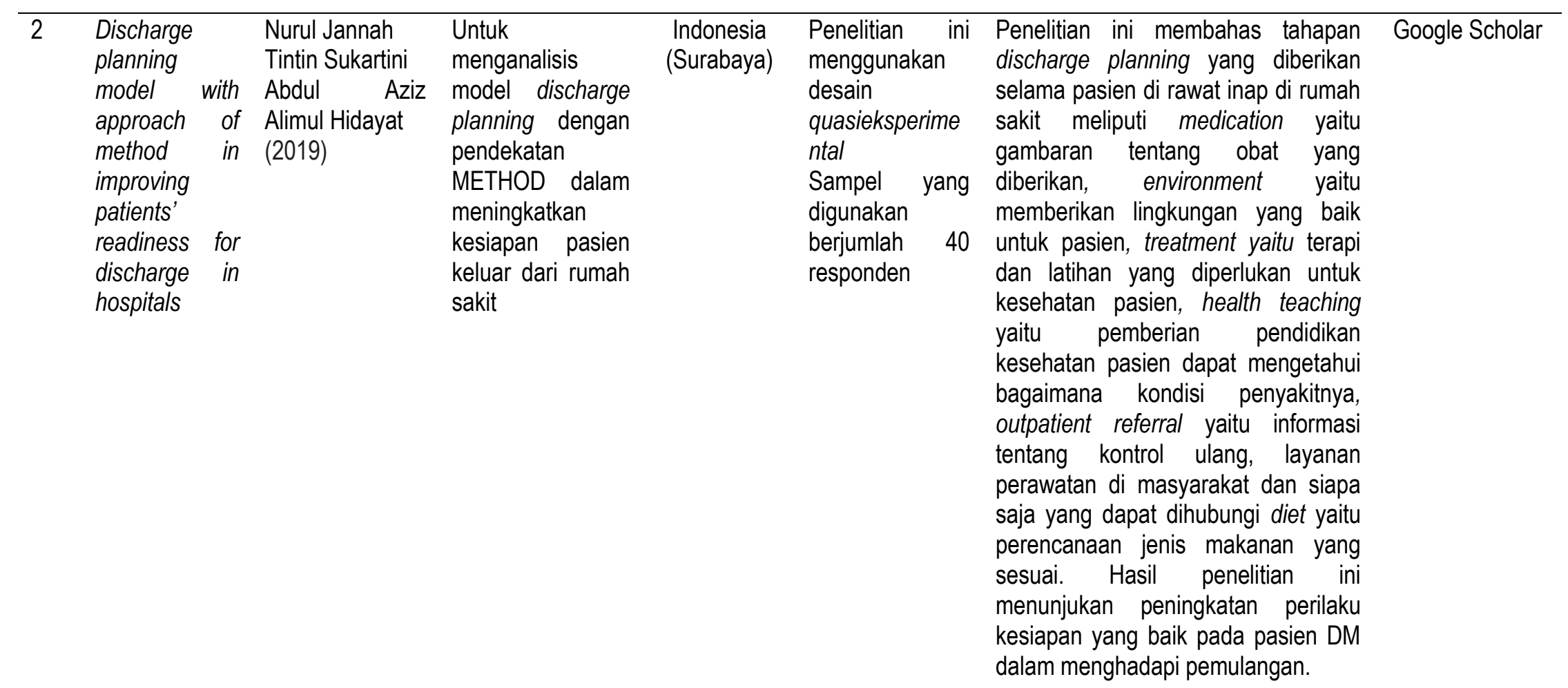

Linda Yulia, Hj. Tuti Pahria, Sandra Pebrianti*

Departemen Keperawatan Medikal Bedah, Fakultas Keperawatan, Universitas Padjadjaran, Indonesia *Email: sandra.pebrianti@unpad.ac.id 
Pelaksanaan discharge planning pada pasien diabetes melitus: Studi literatur

\begin{tabular}{|c|c|c|c|c|c|c|c|}
\hline 3 & $\begin{array}{l}\text { The evaluation } \\
\text { of hospital } \\
\text { discharge plan } \\
\text { effects on the } \\
\text { self-caring } \\
\text { ability of the } \\
\text { patients } \\
\text { suffering type- } \\
2 \text { diabetes: a } \\
\text { randomized } \\
\text { clinical trial }\end{array}$ & $\begin{array}{ll}\text { Zahra Rostami, } & \text { Reidarali Abedi, } \\
\text { Heidid Najafi } \\
\text { Majid } \\
\text { Kalyani. } \\
\text { (2016) }\end{array}$ & $\begin{array}{l}\text { Untuk } \\
\text { mengevaluasi } \\
\text { pengaruh } \\
\text { implementasi } \\
\text { perencanaan } \\
\text { pulang di rumah } \\
\text { sakit pada } \\
\text { kemampuan } \\
\text { perawatan diri } \\
\text { pasien yang } \\
\text { menderita } \\
\text { diabetes tipe } 2 \text { di } \\
\text { rumah sakit }\end{array}$ & Iran & $\begin{array}{l}\text { Penelitian ini } \\
\text { menggunakan } \\
\text { desain semi- } \\
\text { eksperimental } \\
\text { Sampel yang } \\
\text { digunakan } \\
\text { berjumlah } 66 \\
\text { responden }\end{array}$ & $\begin{array}{l}\text { Penelitian ini menjelaskan tahapan } \\
\text { discharge planning dibagi menjadi } \\
\text { dua tahap. Pada tahap pertama } \\
\text { diberikan selama pasien di rawat inap } \\
\text { yang ditujukan untuk meningkatkan } \\
\text { kemampuan perawatan diri pasien } \\
\text { meliputi aktivitas fisik, pengaturan } \\
\text { makanan seperti frekuensi konsumsi } \\
\text { karbohidrat, frekuensi konsumsi } \\
\text { makanan berlemak, perawatan kaki, } \\
\text { dan penggunaan obat. Kemudian } \\
\text { Tahap kedua setelah pasien keluar } \\
\text { dari rumah sakit diberikan program } \\
\text { tindak lanjut dengan dua panggilan } \\
\text { telepon dan sesi pelatihan selama } \\
\text { sebulan. } \\
\text { Hasil penelitian menunjukan } \\
\text { setelah dilakukan implementasi } \\
\text { discharge planning ada perbedaan } \\
\text { yang signifikan secara statistik dalam } \\
\text { nilai (p=0,05) terhadap peningkatan } \\
\text { kemampuan perawatan diri pada } \\
\text { pasien DM. }\end{array}$ & Pubmed \\
\hline 4 & $\begin{array}{l}\text { Effects of an } \\
\text { intensive } \\
\text { discharge } \\
\text { intervention on } \\
\text { medication } \\
\text { adherence, } \\
\text { glycemic } \\
\text { control, and } \\
\text { readmission }\end{array}$ & $\begin{array}{l}\text { Cherlie Magny- } \\
\text { Normilus, } \\
\text { Nyryan V. } \\
\text { Nolido, } \\
\text { Jorge C. } \\
\text { Borges, } \\
\text { Maureen Brady, } \\
\text { Stephanie } \\
\text { Labonville, }\end{array}$ & $\begin{array}{l}\text { Tujuan dari } \\
\text { penelitian ini } \\
\text { adalah untuk } \\
\text { merancang, } \\
\text { mengimplementas } \\
\text { ikan, dan } \\
\text { mengevaluasi } \\
\text { upaya untuk } \\
\text { meningkatkan }\end{array}$ & $\begin{array}{c}\text { Boston } \\
\text { Amerika } \\
\text { serikat }\end{array}$ & $\begin{array}{l}\text { Penelitian ini } \\
\text { mengunakan } \\
\text { desain single- } \\
\text { site, parallel- } \\
\text { group, } \\
\text { randomized } \\
\text { controlled } \\
\text { trial yang } \\
\text { Sampel yol }\end{array}$ & $\begin{array}{l}\text { Penelitian ini menjelaskan dua } \\
\text { tahapan discharge planning. Tahap } \\
\text { pertama selama pasien di rawat inap, } \\
\text { pasien diberikan pendidikan } \\
\text { mengenai diagnosis primer, } \\
\text { perawatan diri setelah pulang dari } \\
\text { rumah sakit, tanda bahaya yang } \\
\text { harus diperhatikan, siapa yang dapat } \\
\text { dihubungi saat terjadi kegawat }\end{array}$ & Pubmed \\
\hline
\end{tabular}

Linda Yulia, Hj. Tuti Pahria, Sandra Pebrianti ${ }^{*}$

Departemen Keperawatan Medikal Bedah, Fakultas Keperawatan, Universitas Padjadjaran, Indonesia

*Email: sandra.pebrianti@unpad.ac.id 
Pelaksanaan discharge planning pada pasien diabetes melitus: Studi literatur

\begin{tabular}{lrllr}
\hline rates & in & Deborah & proses discharge & digunakan \\
patients & with & Williams, & planning, dalam & berjumlah \\
type & 2 Jane Soukup, & kepatuhan obat- & responden \\
diabetes & & Stuart Lipsitz, obatan, kontrol & \\
& & Margo Hudson, & glikemik, dan \\
& and Jeffrey L. mengurangi & \\
Schnipper & penerimaan & \\
& $(2019)$ & kembali pada \\
& & pasien rawat inap \\
& dengan diabetes.
\end{tabular}

daruratan dan janii temu. Selain itu

180 pemberian konseling dari apoteker rawat inap untuk mengidentifikasi dan mengatasi hambatan terhadap kepatuhan pengobatan mengkonfirmasikan rekonsiliasi pengobatan, dan mendidik pasien tentang rejimen pengobatan. Tahap selanjutnya setelah pasien keluar dari rumah sakit, diberikan tindak lanjut panggilan telepon oleh perawat dalam waktu 48 jam setelah keluar dari rumah sakit. Perawat melakukan kunjungan ke rumah pasien untuk mengevaluasi kemampuan pasien dalam memonitor kontrol glukosa dan memberikan insulin di rumah, dan informasi penyedia layanan rawat jalan sesuai kebutuhan. Serta tindak lanjut di klinik dengan perawat dan apoteker (yang juga seorang pendidik diabetes bersertifikat) dalam waktu 3 hari dan tindak lanjut dengan dokter dalam waktu 1 minggu setelah keluar dari rumah sakit.

Hasil penelitian ini menunjukan pasien memiliki kepatuhan lebih besar terhadap pengobatan dan memiliki penurunan glikemik.

Linda Yulia, Hj. Tuti Pahria, Sandra Pebrianti*

Departemen Keperawatan Medikal Bedah, Fakultas Keperawatan, Universitas Padjadjaran, Indonesia *Email: sandra.pebrianti@unpad.ac.id 
Pelaksanaan discharge planning pada pasien diabetes melitus: Studi literatur

\begin{tabular}{|c|c|c|c|c|c|c|c|}
\hline 5 & $\begin{array}{l}\text { Evaluating the } \\
\text { effect of } \\
\text { discharge } \\
\text { planning on } \\
\text { glycosylated } \\
\text { hemoglobin } \\
\text { level in type } 2 \\
\text { diabetic } \\
\text { patients who } \\
\text { referred to the } \\
\text { vasei hospital } \\
\text { in sabzevar, } \\
\text { iran: an an } \\
\text { interventional } \\
\text { study }\end{array}$ & $\begin{array}{l}\text { Alemeh } \\
\text { Dehnabi, Hamid } \\
\text { Radsepehr dan } \\
\text { Hassan } \\
\text { Navipour } \\
(2018)\end{array}$ & $\begin{array}{l}\text { Tujuan dari } \\
\text { penelitian ini } \\
\text { adalah untuk } \\
\text { menilai dampak } \\
\text { discharge } \\
\text { planning pada } \\
\text { pengurangan } \\
\text { hemoglobin } \\
\text { glikosilasi pada } \\
\text { pasien DM tipe } 2\end{array}$ & Iran & $\begin{array}{l}\text { Penelitian ini } \\
\text { mengunakan } \\
\text { desain quasi- } \\
\text { experimental } \\
\text { Sampel pada } \\
\text { penelitian ini } \\
\text { berjumlah } \quad 70 \\
\text { responden. }\end{array}$ & 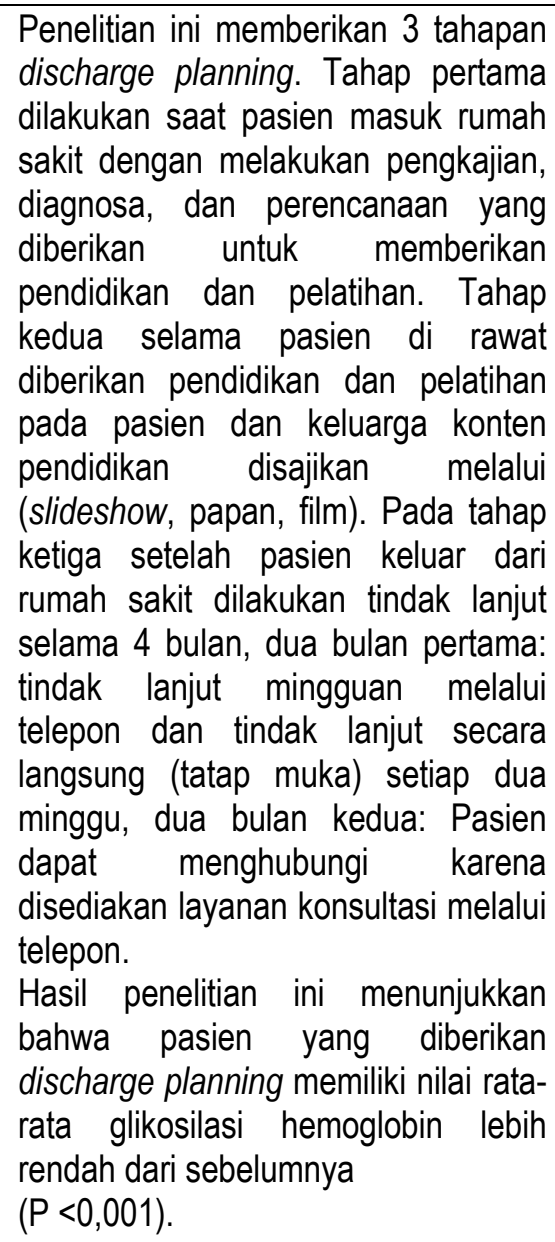 & Pubmed \\
\hline
\end{tabular}

Linda Yulia, Hj. Tuti Pahria, Sandra Pebrianti*

Departemen Keperawatan Medikal Bedah, Fakultas Keperawatan, Universitas Padjadjaran, Indonesia *Email: sandra.pebrianti@unpad.ac.id 
Pelaksanaan discharge planning pada pasien diabetes melitus: Studi literatur

\begin{tabular}{|c|c|c|c|c|c|c|c|c|}
\hline 6 & $\begin{array}{l}\text { Impact of } \\
\text { inpatient } \\
\text { diabetes } \\
\text { management, } \\
\text { education, and } \\
\text { improved } \\
\text { discharge } \\
\text { transition on } \\
\text { glycemic } \\
\text { control } 12 \\
\text { months after } \\
\text { discharge }\end{array}$ & $\begin{array}{l}\text { Deborah } \\
\text { Wexler } \\
\text { Beauharnais } \\
\text { Susan Regan } \\
\text { David } \\
\text { Nathan } \\
\text { Enrico Cagliero } \\
\text { Mary E. Larkin } \\
\text { (2012) }\end{array}$ & j. & $\begin{array}{l}\text { Tujuan penelitian } \\
\text { ini untuk } \\
\text { menentukan } \\
\text { apakah } \\
\text { manajemen } \\
\text { pendidikan dan } \\
\text { perencanaan } \\
\text { pulang akan } \\
\text { meningkatkan } \\
\text { kontrol glikemik } \\
\text { pada pasien } \\
\text { dengan diabetes } \\
\text { tipe 2 setelah } \\
\text { keluar dari rumah } \\
\text { sakit }\end{array}$ & $\begin{array}{l}\text { Amerika } \\
\text { serikat }\end{array}$ & $\begin{array}{l}\text { Penelitian ini } \\
\text { mengunakan } \\
\text { desain kohort } \\
\text { retrospekti } \\
\text { Sampel yang } \\
\text { digunakan } \\
\text { berjumlah } 31 \\
\text { responden }\end{array}$ & $\begin{array}{l}\text { Discharge planning pada penelitian } \\
\text { ini dilakukan dalam } 2 \text { tahap. Tahap } \\
\text { pertama selama masa rawat inap } \\
\text { diberikan pendidikan diabetes yang } \\
\text { berfokus pada keterampilan } \\
\text { pengelolaan diabetes, penggunaan } \\
\text { insulin, tanda gejala hipo dan } \\
\text { hiperglikemia, diet, perawatan kaki } \\
\text { dan kulit, dan olahraga, serta } \\
\text { didokumentasikan menggunakan } \\
\text { templat standar oleh pendidik } \\
\text { endokrinologis dan perawat. Tahap } \\
\text { kedua setelah pasien keluar dari } \\
\text { rumah sakit pasien menerima } \\
\text { instruksi pengobatan untuk pulang } \\
\text { yang dicetak pada templat satu } \\
\text { halaman yang menguraikan rejimen } \\
\text { dan menyarankan perubahan dalam } \\
\text { makanan dan aktivitas. Selain itu, } \\
\text { ringkasan singkat dari perubahan } \\
\text { obat diabetes, pelatihan saat di } \\
\text { rumah sakit. Hasil penelitian ini } \\
\text { menunjukan discharge planning } \\
\text { dapat meningkatkan kontrol glikemik } \\
\text { hingga } 12 \text { bulan setelah keluar dari } \\
\text { rumah sakit pada pasien dengan hasil } \\
\text { terdapat pengurangan HbA1c rata- } \\
\text { rata } \\
\text { sebesar } 0.6 \%\end{array}$ & Science Direct \\
\hline
\end{tabular}

Linda Yulia, Hj. Tuti Pahria, Sandra Pebrianti*

Departemen Keperawatan Medikal Bedah, Fakultas Keperawatan, Universitas Padjadjaran, Indonesia *Email: sandra.pebrianti@unpad.ac.id 
Pelaksanaan discharge planning pada pasien diabetes melitus: Studi literatur

\begin{tabular}{|c|c|c|c|c|c|c|c|}
\hline 7 & $\begin{array}{l}\text { Pengaruh } \\
\text { IDEAL } \\
\text { discharge } \\
\text { planning } \\
\text { terhadap } \\
\text { kemampuan } \\
\text { self care } \\
\text { pasien diabetes } \\
\text { mellitus }\end{array}$ & $\begin{array}{l}\text { Febrianti Astuti } \\
\text { Suhartono } \\
\text { Madya Sulisno } \\
\text { (2016) }\end{array}$ & $\begin{array}{l}\text { Untuk mengetahui } \\
\text { perbandingan } \\
\text { pengaruh IDEAL } \\
\text { discharge } \\
\text { planning diruang } \\
\text { rawat inap RSUD } \\
\text { Kota Mataram } \\
\text { dengan discharge } \\
\text { planning rutin } \\
\text { yang diberikan } \\
\text { diruang rawat inap } \\
\text { RSUD Provinsi } \\
\text { NTB. }\end{array}$ & $\begin{array}{l}\text { Indonesia } \\
\text { (RSUD Kota } \\
\text { Mataram } \\
\text { dan RSUD } \\
\text { Provinsi } \\
\text { NTB) }\end{array}$ & $\begin{array}{l}\text { Desain } \\
\text { penelitian quasi } \\
\text { Eksperiment } \\
\text { Sampel yang } \\
\text { digunakan } \\
\text { berjumlah } 40 \\
\text { responden }\end{array}$ & $\begin{array}{l}\text { Penelitian ini melakukan beberapa } \\
\text { tahapan discharge planning dimulai } \\
\text { sejak pasien masuk sampai keluar } \\
\text { dari rumah sakit. dimulai dengan } \\
\text { melakukan diskusi mengenai } \\
\text { masalah penyakit antara perawat } \\
\text { dengan pasien dan keluarganya } \\
\text { kemudian memberikan pendidikan } \\
\text { bagaimana cara mengatasi masalah } \\
\text { yang dihadapi pasien dan } \\
\text { keluarganya serta memberikan } \\
\text { pemahaman yang lebih baik tentang } \\
\text { perawatan diri pasien diabetes seperti } \\
\text { penggunaan obat, mengidentifikasi } \\
\text { tanda gejala atau potensi masalah } \\
\text { yang bisa timbul, menjelaskan hasil } \\
\text { tes dan membuat janji tindak lanjut } \\
\text { atau kontrol. Hasil penelitian ini } \\
\text { menunjukan adanya perubahan } \\
\text { kemampuan self care yang lebih baik } \\
\text { pada pasien DM }\end{array}$ & Google Scholar \\
\hline
\end{tabular}

Linda Yulia, Hj. Tuti Pahria, Sandra Pebrianti*

Departemen Keperawatan Medikal Bedah, Fakultas Keperawatan, Universitas Padjadjaran, Indonesia *Email: sandra.pebrianti@unpad.ac.id 
Pelaksanaan discharge planning pada pasien diabetes melitus: Studi literatur

\begin{tabular}{|c|c|c|c|c|c|c|c|}
\hline 8 & $\begin{array}{l}\text { Effect of LIMA } \\
\text { discharge } \\
\text { planning } \\
\text { model on } \\
\text { discharge } \\
\text { readiness } \\
\text { among } \\
\text { patients with } \\
\text { diabetes } \\
\text { mellitus }\end{array}$ & $\begin{array}{l}\text { Eka Yulia Fitri, } \\
\text { Dhona Andini, } \\
\text { Jum Natosba } \\
\text { (2020) }\end{array}$ & $\begin{array}{l}\text { Untuk mengetahui } \\
\text { pengaruh } \\
\text { penggunaan } \\
\text { discharge } \\
\text { planning model } \\
\text { LIMA terhadap } \\
\text { kesiapan pasien } \\
\text { dan keluarga } \\
\text { dalam } \\
\text { menghadapi } \\
\text { pemulangan. }\end{array}$ & $\begin{array}{l}\text { Indonesia } \\
\text { Palembang }\end{array}$ & $\begin{array}{l}\text { Penelitian ini } \\
\text { menggunakan } \\
\text { studi kolerasi } \\
\text { dengan } \\
\text { pendekatan } \\
\text { quasi } \\
\text { eksperimental } \\
\text { Sampel yang } \\
\text { digunakan } \\
\text { berjumlah } 31 \\
\text { responden }\end{array}$ & $\begin{array}{l}\text { Penelitian ini menjelaskan beberapa } \\
\text { tahapan discharge planning selama } \\
\text { pasien di rawat dengan } \\
\text { mengidentifikasi kebutuhan discharge } \\
\text { planning bagi pasien dan keluarga } \\
\text { (perawatan diri di rumah, penjelasan } \\
\text { tentang obat-obatan, pengenalan } \\
\text { tanda dan gejala yang harus } \\
\text { diwaspadai oleh pasien dan keluarga, } \\
\text { penjelasan hasil tes laboratorium atau } \\
\text { pemeriksaan diagnostik, jadwal } \\
\text { kontrol); penggunaan metode tiga } \\
\text { langkah dalam pelaksanaan } \\
\text { discharge planning (saat pasien baru } \\
\text { dirawat di rumah sakit, satu hari } \\
\text { sebelum pasien diizinkan untuk } \\
\text { pulang, dan pada hari kepulangan } \\
\text { pasien); dan evaluasi terhadap } \\
\text { kesiapan pulang pasien dan keluarga } \\
\text { Hasil penelitian ini menunjukkan } \\
\text { bahwa setelah pemberian discharge } \\
\text { planning terjadi peningkatan kesiapan } \\
\text { pulang pada pasien DM }\end{array}$ & Google Scholar \\
\hline
\end{tabular}

Linda Yulia, Hj. Tuti Pahria, Sandra Pebrianti*

Departemen Keperawatan Medikal Bedah, Fakultas Keperawatan, Universitas Padjadjaran, Indonesia *Email: sandra.pebrianti@unpad.ac.id 
Pelaksanaan discharge planning pada pasien diabetes melitus: Studi literatur

\begin{tabular}{|c|c|c|c|c|c|c|c|}
\hline 9 & $\begin{array}{l}\text { Discharge } \\
\text { planning } \\
\text { terintegrasi } \\
\text { dalam } \\
\text { pelayanan } \\
\text { klien } \\
\text { diabetes } \\
\text { mellitus di } \\
\text { ruang rawat } \\
\text { inap penyakit } \\
\text { dalam RSUD } \\
\text { solok }\end{array}$ & $\begin{array}{l}\text { Tintin Sumarni, } \\
\text { Yulastri, } \\
\text { Abd Gafar } \\
\text { (2017) }\end{array}$ & $\begin{array}{l}\text { Untuk mengetahui } \\
\text { pengaruh } \\
\text { penerapan } \\
\text { discharge } \\
\text { planning } \\
\text { terintegrasi } \\
\text { terhadap } \\
\text { pengetahuan } \\
\text { pasien tentang } \\
\text { penatalaksanaan } \\
\text { DM }\end{array}$ & $\begin{array}{c}\text { Indonesia } \\
\text { (Solok) }\end{array}$ & $\begin{array}{l}\text { Penelitian } \\
\text { menggunakan } \\
\text { desain quasi } \\
\text { eksperimen } \\
\text { Sampel yang } \\
\text { digunakan } 39 \\
\text { responden }\end{array}$ & $\begin{array}{l}\text { Penelitian ini menjelaskan tentang } \\
\text { cara pemberian pendidikan discharge } \\
\text { planning dengan menggunakan } \\
\text { modul yang diberikan secara jelas } \\
\text { mengenai penatalaksanaan DM akan } \\
\text { memberikan pemahaman yang baik } \\
\text { kepada pasien. Sedangkan pada } \\
\text { tahapan } 4 \text { kali, yaitu pada saat awal } \\
\text { masuk rumah sakit, selama pasien di } \\
\text { rawat dan } 2 \text { kali pemberian sebelum } \\
\text { pasien keluar dari rumah sakit } \\
\text { dengan melibatkan tim multidisiplin } \\
\text { yang mewakili masing-masing profesi } \\
\text { terdiri dari dokter perawat, ahli gizi, } \\
\text { dan farmasi. } \\
\text { Hasil penelitian menunjukan bahwa } \\
\text { terdapat peningkatan pengetahuan } \\
\text { pasien tentang penataksanaan DM } \\
\text { setelah penerapan discharge } \\
\text { planning. }\end{array}$ & Google Scholar \\
\hline
\end{tabular}

Linda Yulia, Hj. Tuti Pahria, Sandra Pebrianti*

Departemen Keperawatan Medikal Bedah, Fakultas Keperawatan, Universitas Padjadjaran, Indonesia *Email: sandra.pebrianti@unpad.ac.id 
Pelaksanaan discharge planning pada pasien diabetes melitus: Studi literatur

\begin{tabular}{|c|c|c|c|c|c|c|c|}
\hline 10 & $\begin{array}{l}\text { Pengaruh } \\
\text { Perencanaan } \\
\text { Pulang } \\
\text { (Discharge } \\
\text { Planning) } \\
\text { Untuk } \\
\text { Menjaga } \\
\text { Kestabilan } \\
\text { Kadar Gula } \\
\text { Darah Pada } \\
\text { Pasien } \\
\text { Diabetes } \\
\text { Mellitus Paska } \\
\text { Rawat Inap }\end{array}$ & $\begin{array}{l}\text { Tati Nurhayati } \\
\text { (2011) }\end{array}$ & $\begin{array}{l}\text { Mengetahui } \\
\text { pengaruh } \\
\text { discharge } \\
\text { planning untuk } \\
\text { menjaga } \\
\text { kestabilan kadar } \\
\text { gula darah pada } \\
\text { pasien diabetes }\end{array}$ & $\begin{array}{l}\text { Indonesia } \\
\text { (Jakarta) }\end{array}$ & $\begin{array}{l}\text { Peneliti } \\
\text { menggunakan } \\
\text { desain quasi } \\
\text { eksperimental, } \\
\text { Sampel yang } \\
\text { digunakan } \\
\text { berjumlah } 8 \\
\text { responden }\end{array}$ & $\begin{array}{l}\text { Penelitian ini menjelaskan tahapan } \\
\text { discharge planning dilakukan sejak } \\
\text { pasien masuk rumah sakit dengan } \\
\text { melakukan pengkajian mengenai } \\
\text { kebutuhan pelayanan kesehatan, } \\
\text { kebutuhan pendidikan, pengkajian } \\
\text { kemampuan fisik dan kognitif, } \\
\text { pengkajian penerimaan diri terhadap } \\
\text { penyakit. Tetapkan diagnosa } \\
\text { keperawatan, rencana, implementasi, } \\
\text { evaluasi kemajuan terus menerus } \\
\text { dan tentukan tujuan } \\
\text { pulang yang relevan. Hasil penelitian } \\
\text { ini menunjukan terdapat penurunan } \\
\text { yang signifikan antara kadar gula } \\
\text { darah sebelum dan sesudah } \\
\text { diberikan discharge planing dengan } \\
\text { derajat kepercayaan } 95 \% \text { dengan } \\
\text { nilai alpha }>0,05 \text {. }\end{array}$ & Google Scholar \\
\hline
\end{tabular}

Linda Yulia, Hj. Tuti Pahria, Sandra Pebrianti*

Departemen Keperawatan Medikal Bedah, Fakultas Keperawatan, Universitas Padjadjaran, Indonesia *Email: sandra.pebrianti@unpad.ac.id 
Berdasarkan tabel diatas diketahui bahwa discharge planning dilakukan dalam beberapa tahapan antara lain: Tahap pertama dimulai sejak pasien masuk rumah sakit dengan melakukan pengkajian, diagnosa, perencanaan, implementasi, dan evaluasi. Tahap kedua selama pasien di rawat di rumah sakit dengan memberikan pendidikan dan pelatihan. Tahap ketiga yaitu setelah pasien keluar dari rumah sakit dengan melakukan tindak lanjut berupa konseling telepon dan kunjungan ke rumah pasien. Pemberian discharge planning berdasarkan beberapa tahapan ini pada dasarnya dapat meningkatkan kepatuhan pasien terhadap pengobatan dan kontrol glikemik.

\section{PEMBAHASAN}

Discharge planning adalah proses dinamis dalam menilai kebutuhan perawatan secara berkelanjutan yang bertujuan untuk memandirikan pasien sehingga pasien dan keluarga memperoleh persiapan yang tepat untuk melakukan perawatan di rumah (Suzuki et al, 2011). Intervensi terhadap tahapan penyampaian discharge planning sangatlah penting karena dapat membantu dalam meningkatkan kemampuan pasien dan keluarga dalam melakukan perawatannya.

Dari hasil penelitian literatur ini sebagian besar artikel yang digunakan menggunakan desain Quasy-exsperimental. Penggunaan literatur dapat dijadikan salah satu tolak ukur kualitas suatu penelitian. Salah satu kriteria yang sangat baik adalah dalam memanfaatkan literatur terkini dan baru dengan jumlah yang banyak sebagai dasar dilakukannya penelitian.

Berdasarkan hasil analisis tabel dari 10 artikel dapat tergambarkan bahwa discharge planning dimulai dari saat pasien masuk ke rumah sakit sebagai dasar penetapan perencanaan berdasarkan kebutuhan pasien dan keluarga. Kunci keberhasilan dalam discharge planning adalah pertukaran informasi antara tenaga kesehatan, pasien dan keluarga. Oleh karena itu, program discharge planning yang efisien harus dilakukan secara bertahap untuk membantu pasien dan keluarga mempersiapkan keterampilan mengelola diri mereka sendiri setelah keluar dari rumah sakit (Rostami et al., 2016; Jannah et al., 2019). Tahapan discharge planning terdiri dari: Tahapan pertama discharge planning dilakukan sejak pasien masuk ke rumah sakit, tahapan discharge planning ini dimulai sejak 24 jam pasien masuk ke rumah sakit dengan melakukan pengkajian, penetapan diagnosa, perencanaan, implementasi dan evaluasi sebagai langkah awal pemberian discharge planning. Proses pengkajian pada tahap ini dilakukan dengan teknik wawancara dengan mengidentifikasi kebutuhan pendidikan dan pelatihan pasien untuk di rumah yang meliputi pengkajian tentang kebutuhan pelayanan kesehatan untuk pasien, pengkajian kemampuan fisik dan fungsi kognitif yang dilakukan secara terus menerus. Pengkajian kebutuhan pendidikan kesehatan untuk pasien dan keluarga seperti informasi tentang penyakit, metode mengendalikan dan mencegah komplikasi, serta pengkajian penerimaan diri pasien terhadap masalah kesehatannya (Dehnabi et al 2017 ; Nurhayati 2011 ; Dehnabi et al 2018).

Setelah mengumpulkan informasi, diagnosis dibuat berdasarkan kebutuhan pasien di bidang nutrisi, latihan, dan pengobatan, yaitu sebagai berikut: Memiliki informasi yang cukup tentang nutrisi diabetes sehubungan dengan kurangnya informasi spesifik sumber daya dengan diet yang tidak sesuai; Melakukan aktivitas yang sesuai sehubungan dengan kurangnya kesadaran akan peran olahraga dalam perawatan diabetes yang ditandai dengan mobilitas kurang dari 1 jam per minggu Memiliki informasi yang cukup tentang pengontrolan glukosa darah, obat-obatan dan keterampilan perawatan diri dalam penggunaan insulin sehubungan dengan kurangnya informasi spesifik dengan suntikan yang benar, penyesuaian dosis dan penggunaan obat-obatan oral yang tidak tepat; Keterampilan perawatan diri dalam bidang kontrol glukosa darah sehubungan dengan kurangnya akses ke perangkat kontrol glukosa darah dan kurangnya sumber daya informasi spesifik karena ketidakmampuan untuk mengontrol glukosa darah; Memiliki informasi yang memadai tentang sifat diabetes dan komplikasinya sehubungan dengan kurangnya sumber daya informasi spesifik, dalam sifat penyakit, dan komplikasi diabetes.

Dalam perencanaan, diberikan dalam enam sesi pertemuan untuk setiap pasien dan setiap sesi berlangsung selama 30-45 menit disesuaikan dengan program yang tergantung pada tingkat kebutuhan pendidikan dan pelatihan pasien. Perencanaan yang telah dibuat kemudian diimplementasikan dimulai dari saat pasien masuk dan berlanjut sampai dua bulan setelah keluar dari rumah sakit. Pada tahap evaluasi dilakukan 
penilaian berdasarkan pengetahuan dan daftar periksa laporan diri pasien.

Pada tahap kedua beberapa penelitian menyebutkan tahapan discharge planning ini yang dilakukan selama pasien di rawat inap yang ditujukan untuk meningkatkan pengetahuan dan kemampuan perawatan diri pasien. Pasien DM selama di rawat diberikan pendidikan tentang informasi penyakit diabetes seperti penjelasan diagnosis primer, hasil tes laboratorium, tanda bahaya yang harus diperhatikan, dukungan yang diperlukan pasien dan keluarga, informasi tentang sumber-sumber pelayanan kesehatan di masyarakat seperti puskesmas dan klinik 24 jam dan siapa yang dapat dihubungi saat terjadi kegawatdaruratan (Wexler et al, 2012 ; Astuti et al, 2016).

Selain pendidikan, pengelolaan penyakit diabetes yang baik harus memberikan pelatihan untuk meningkatkan keterampilan diri pasien dalam pengelolaan penyakit saat berada di rumah (Nurhayati 2011 ; Rostami et al, 2016). Untuk meningkatkan keterampilan diri pasien berfokus pada pengaturan makanan atau diet seperti anjuran makanan yang harus dikonsumsi dan yang harus dihindari, memberikan metode penyusunan diit sehari-hari, penyesuaian porsi makan, pengaturan frekuensi makanan karbohidrat dan berlemak, serta penggantian gula untuk mencegah fluktuasi kadar glukosa darah setiap mengupayakan kadar glukosa darah mendekati normal melalui cara-cara yang aman, informasi aktivitas fisik pada pasien diabetes seperti program berjalan harian, penggunaan obat (cara, waktu dan dosis obat), penggunaan injeksi insulin (tempat injeksi insulin, penyesuaian jarum suntik, dan unit insulin) dan efek samping dari penggunaan. Selain itu pelatihan pada pasien DM berupa perawatan kaki dan kulit, kontrol glukosa darah, dan manajemen hipo dan hiperglikemia yang didokumentasikan menggunakan templat standar oleh perawat (Fitri et al, 2020; Wexler et al, 2012). Penerapan pendidikan dan pelatihan discharge planning ini dapat diberikan dengan jelas menggunakan modul tentang penatalaksanaan DM, akan memberikan pemahaman yang baik kepada pasien sehingga pasien tidak kebingungan dalam mencari dan memahami penjelasan yang telah disampaikan (Sumarni et al, 2017).

Pada tahap ketiga diberikan setelah pasien keluar dari rumah sakit memberikan tindak lanjut selama periode 2 bulan. Selama bulan pertama pasien ditindaklanjuti dengan konseling panggilan telepon seminggu sekali dan kunjungan dilakukan setiap dua minggu. Perawat melakukan kunjungan ke rumah pasien untuk mengevaluasi kemampuan pasien dalam memonitor kontrol glukosa dan memberikan insulin di rumah, dan informasi penyedia layanan rawat jalan sesuai kebutuhan. Dalam periode dua bulan kedua, pasien dibekali formulir kontrol dan booklet yang mencakup asupan makanan, aktivitas fisik, dan penggunaan obat di rumah. Pasien juga dapat menghubungi karena disediakan layanan konsultasi melalui telepon (Normilus et al, 2019 ; Rostami et al, 2016 ; Dehnabi et al, 2018).

Pemberian discharge planning berdasarkan beberapa tahapan ini pada dasarnya dapat meningkatkan kepatuhan pasien terhadap pengobatan dan kontrol glikemik. Pasien yang diberikan discharge planning secara bertahap meningkatkan kontrol glikemik hingga 12 bulan setelah keluar dari rumah sakit pada pasien dengan hasil terdapat pengurangan $\mathrm{HbA} 1 \mathrm{c}$ ratarata sebesar $0.6 \%$ (Wexler et al, 2012). Hasil pemberian discharge planning memiliki pengaruh terhadap peningkatan kemampuan perawatan diri pada pasien DM (Rostami et al, 2016 ; Astuti et al,2020). Serta peningkatan kesiapan pada pasien dalam menghadapi pemulangan (Jannah et al, 2019; Fitri et al, 2020).

\section{SIMPULAN}

Tahapan discharge planning dibagi menjadi 3 tahap yaitu tahap pertama dimulai sejak pasien masuk rumah sakit dengan melakukan pengkajian, diagnosa, perencanaan, implementasi, dan evaluasi. Tahap kedua selama pasien dirawat dengan memberikan pendidikan dan pelatihan meliputi informasi tentang penyakit, tanda dan gejala penyakit, hal-hal yang harus dihindarkan dari gangguan kesehatan yang dialami dan komplikasi, serta informasi tentang sumber-sumber pelayanan kesehatan di masyarakat, penggunaan obat (cara, waktu dan dosis obat), penggunaan injeksi insulin (tempat injeksi insulin, sesuai jarum suntik, dan unit insulin), diet, aktivitas fisik, manajemen hipo dan hiperglikemia, perawatan kaki, dan kontrol glukosa darah. Tahap ketiga yaitu setelah pasien keluar dari rumah sakit dengan melakukan tindak lanjut berupa konseling telepon dan kunjungan ke rumah pasien. 


\section{SARAN}

\section{Bagi Rumah Sakit}

Dalam hal ini diharapkan rumah sakit dapat mensosialisasikan pelaksanaan discharge planning secara bertahap dan berstruktur guna menunjang kontinuitas perawatan lanjutan dan pemantauan untuk mengetahui tingkat keberhasilan pelaksanaan yang sudah dilakukan serta demi meningkatkan mutu pelayanan dan kepuasan pasien dan keluarga. Kajian literatur ini diharapkan mampu menjadi bahan informasi mengenai tahapan discharge planning yang harus diberikan pada pasien DM dalam penerapan discharge planning oleh perawat serta sebagai pertimbangan agar dapat melaksanakan discharge planning secara optimal.

\section{DAFTAR PUSTAKA}

Agustin, R. (2017). Optimalisasi pelaksanaan discharge planning melalui pengembangan model discharge planning terintegrasi pelayanan keperawatan. Jurnal Keperawatan Muhammadiyah.

https://doi.org/10.30651/jkm.v2i1.921

Alloghani, M., Aljaaf, A., Hussain, A., Baker, T., Mustafina, J., Al-jumeily, D., \& Khalaf, M. (2019). Implementation of machine learning algorithms to create diabetic patient readmission profiles. BMC Medical Informatics and Decision Making, 19(Suppl 9), 1-16. https://doi.org/10.1186/s12911-019-0990-x

Amtsalina, A. (2016). Hubungan kepatuhan mengontrol gula darah dengan kejadian rawat inap ulang pasien diabetes melitus. (2014), 115.

Astuti, F., Suhartono, S., \& Sulisno, M. (2016). Pengaruh ideal discharge planning terhadap kemampuan self care pasien diabetes melitus: studi pada pasien diabetes melitus di RSUD Kota Mataram Dan RSUD Provinsi NTB (Doctoral dissertation, Diponegoro University). http://eprints.undip.ac.id/47766/

Baethge, C., Goldbeck-wood, S., \& Mertens, S. (2019). SANRA - a scale for the quality assessment of narrative review articles. 8, 2-8. https://doi.org/10.1186/s41073-019-0064-8
Darliana, D. (2012). Discharge planning dalam keperawatan Discharge Planning in Nursing ; A Literature Review. Idea Nursing Journal.

Dehnabi, A., Navipour, H., Radsepehr, H., \& Tadayonfar, M. A. R. (2017). Effect of discharge planning on metabolic factors in type 2 diabetic patients. Journal of Client-Centered Nursing Care, 3(4), 251-262.. doi: 10.32598/jccnc.3.4.251

Dehnabi, A., Radsepehr, H., \& Navipour, H. (2018). Evaluating the effect of discharge planning on glycosylated hemoglobin level in type 2 diabetic patients who referred to the Vasei Hospital in Sabzevar, Iran: An Interventional Study. Medical-Surgical Nursing Journal, 7(3).https://dx.doi.org/\%2010.5812/ms ni. 87197

Daulay, M. (2018). Hubungan kadar HBA1C terhadap kadar glukosa darah puasa pada pasien penderita diabetes melitus tipe 2 di rumah Sakit Umum Pusat Haji Adam Malik. http://repositori.usu.ac.id/handle/123456789/10 945

Demiris, G., Oliver, D. P., \& Washington, K. T. (2019). Defining and analyzing the problem. Behavioral intervention research in hospice and palliative care, 27-39. https://doi.org/10.1016/b978-0-12-8144497.00003-x

Federation, I. D. (2015). IDF Diabetes Atlas Seventh.

Fitri, E. Y., Andini, D., \& Natosba, J. (2020). Effect of LIMA discharge planning model on discharge readiness a mong patients with diabetes mellitus. 25(Sicph 2019), 298-301. https://dx.doi.org/10.2991/ahsr.k.200612.041

Graham, J., Gallagher, R., \& Bothe, J. (2013). Nurses' discharge planning and risk assessment: behaviours, understanding and barriers. Journal of clinical nursing, 22(15-16), 2338-2346.

https://onlinelibrary.wiley.com/doi/epdf/10.1111/ jocn. 12179 
Hardivianty, C. (2017). Evaluasi pelaksanaan discharge planning di Muhammadiyah Gamping Yogyakarta. 1(1), 21-34.

Jannah, N., Sukartini, T., \& Hidayat, A. A. A. (2019). Discharge planning model with approach of method in improving patients' readiness for discharge in hospitals. Indian Journal of Public Health Research \& Development, 10(1). doi: 10.5958/09765506.2019.00057.3

Magny-Normilus, C., Nolido, N. V., Borges, J. C., Brady, M., Labonville, S., Williams, D., \& Schnipper, J. L. (2019). Effects of an intensive discharge intervention on medication adherence, glycemic control, and readmission rates in patients with type 2 diabetes. Journal of patient safety. https://www.ncbi.nlm.nih.gov/pmc/articles/PMC 7647006/

Natasia, N. (2017). Hubungan antara faktor motivasi dan supervisi dengan kinetja perawat dalam pendokumentasian discharge planning di RSUD Gambitan Kota Kediri, Jurnal aplikasi Manajemen. 97(4), 393-403.

Nurhayati, T. (2011). Pengaruh perencanaan pulang (discharge planning) untuk menjaga kestabilan kadar gula darah pada pasien diabetes mellitus paska rawat inap di Yanmasum Paviliun Rspad Gatot Soebroto Jakarta. Riset Keperawatan.

Pujiastuti, E. (2016). Hubungan pengetahuan dan motivasi dengan kepatuhan diet pada pasien diabetes mellitus tipe ii di poliklinik penyakit dalam rsud dr. soehadi prijonegoro sragen.

Purwanti, N., Yusuf, A., \& Suprajitno. (2016). Pengaruh discharge planning berbasis video dengan pendekatan family centered nursing terhadap kemampuan keluarga merawat klien skizofrenia. 204-213. https://doi.org/10.33086/jhs.v10i2.131
Puspita, F. A., \& Rakhma, L. R. (2018). Hubungan lama kepesertaan prolanis dengan tingkat pengetahuan gizi dan kepatuhan diet pasien diabetes mellitus di puskesmas gilingan surakarta. Jurnal Dunia Gizi, 1(2), 101-111. https://doi.org/10.33085/jdg.v1i2.3076

Ramayanti, E. D., \& Huda, Y. N. (2014). Pengaruh Discharge Planning Terhadap Kesiapan Pulang Pada Pasien Diabetes Melitus. Java Health Jounal, 1(2), 81-88.Jane, G., Galakher, R. \& Bothe, J. (2013). Nurse Discharge Planning and Risk assessment: Behaviour, understanding and barrier. Journal of Clinical Nursing, ed: 22. Bl.

Rostami, Z., Abedi, H., \& Kalyani, M. N. (2016). The evaluation of hospital discharge plan effects on the self-caring ability of the patients suffering type-2 diabetes: A randomized clinical trial. International Journal of Medical Research \& Health Sciences, 5(2), 92-98.

Sumarni, T., \& Gafar, A. (2019). Discharge Planning Terintegrasi Dalam Pelayanan Klien Diabetes Mellitus Di Ruang Rawat Inap Penyakit Dalam Rsud Solok Tahun 2017. 14(1), 63-70.

Suryadi, R. F. (2013). Hubungan peran educator perawat dalam discharge planning dengan tingkat kepatuhan pasien rawat inap untuk kontrol di Rumah Sakit Paru Kabupaten Jember.

http://repository.unej.ac.id/handle/123456789/3 285

Suzuki, V. F., Carmona, E. V., \& Lima, M. H. M. (2011). Planning the hospital discharge of patients with diabetes: the construction of a proposal. Revista Da Escola de Enfermagem Da USP., 2011; 45(2):515-20. doi: https://doi.org/10.1590/S008062342011000200032.

Soegondo, S., Soewondo, P., \& Subekti, I. (2013). Penatalaksanaan Diabetes Melitus Terpadu. Edisi ke 2. 
Tage, P. K. S., Novieastari, E., \& Suhendri, A. (2018). Optimalisasi Pelaksanaan Discharge Planning Terstruktur Dan Terintegrasi. Chmk Nursing Scientific Journal, 2(April).

Taharuddin, T. (2017). Efektifitas Pelaksanaan Model Konservasi Discharge Planning Terstruktur Terhadap Perubahan Derajat Luka Dan Kadar Glukosa Darah Pada Pasien Ulkus Diabetikum. Care: Jurnal IImiah IImu Kesehatan, 5(3), 403-417. doi: https://dx.doi.org/10.33366/cr.v5i3.708

Wexler, D. J., Beauharnais, C. C., Regan, S., Nathan, D. M., Cagliero, E., Larkin, M. E., \& Cde, M. S. R. N. (2012). Impact of inpatient diabetes management, education, and improved discharge transition on glycemic control 12 months after discharge. Diabetes Res Clin Pract, 98(2), 249-256. doi: https://doi.org/10.1016/j.diabres.2012.09.016.I mpact

Wu, Y., Ding, Y., Tanaka, Y., \& Zhang, W. (2014). Risk factors contributing to type 2 diabetes and recent advances in the treatment and prevention. International Journal of Medical Sciences, 11(11), $1185 . \quad$ doi: 10.7150/ijms. 10001.
World Health Organization [WHO]. (2016a). Diabetes facts, 1-2. doi: https://doi.org/10.1097/00152193-198704000- 00001

World Health Organization [WHO]. (2016b). Global Report on Diabetes. Isbn, 978, 88. https://doi.org/ISBN 9789241565257

Wrobleski, D.M.S. et al. (2014). Discharge Planning Rounds to the Bedside : A Patientand Family-Centered Approach. , 23(2).

Zahroh, R., \& Azkiyawati, M. (2015). Penerapan diabetes self management education meningkatkan pengetahuan, sikap dan pengendalian glukosa darah (Diabetes Self Management Education (DSME) toward Knowledge-Attitude and Control Blood Glucose). Journals of Ners Community, 6(2), 107-114.

http://journal.unigres.ac.id/index.php/JNC/articl e/view/42/420 